\title{
Hukum Pernikahan Beda Agama menurut Ulama Indonesia
}

\author{
Wiwin Siti Aminah \\ Institut Agama Islam Darussalam (IAID) Ciamis, Jawa Barat \\ Email: wiwinstaminah.iaid@gmail.com \\ Roby Awaludin \\ Institut Agama Islam Darussalam (IAID) Ciamis, Jawa Barat \\ Irfan Hilmi \\ Institut Agama Islam Darussalam (IAID) Ciamis, Jawa Barat
}

\begin{abstract}
ABSTRAK
Pernikahan adalah salah satu Sunnatullah yang umum berlaku pada semua makhluk Tuhan, baik pada manusia, hewan, maupun tumbuh-tumbuhan. Dengan melakukan pernikahan seseorang akan terhindarlah dari godaan setan, baik godaan dari penglihatan mata maupun alat kelamin atau syahwat. Sebagaimana Rasulullah telah memerintahkan untuk menikah dengan orang yang kita senangi dengan memberikan berapa pertimbangan di antaranya: hartanya, kecantikannya, keturunannya, dan terutama dalam pertimbangan masalah agamanya. Di Era modern sekarang marak terjadi peraktek pernikahan beda agama, terutama di Indonesia. Dengan adanya persoalan demikian, perlu adanya pengambilan kesimpualan hukum yang berkaitan dengan pernikahan beda agama.
\end{abstract}

\begin{abstract}
Marriage is one of the Sunnatullah which generally applies to all creatures of God, both in humans, animals and plants. By doing a marriage someone will be protected from the temptations of Satan, both temptations from eyesight and genitals or lust. As the Messenger of Allah has ordered to marry the person we like by giving them several considerations including: his property, his beauty, his offspring, and especially in considering his religious problems. In the modern era there are now many interfaith marriage practices, especially in Indonesia. With such problems, it is necessary to take legal conclusions relating to interfaith marriages.
\end{abstract}

Keywords: Marriage, religion differences 


\section{PENDAHULUAN}

Pernikahan adalah salah satu Sunnatullah yang umum berlaku pada semua makhluk Tuhan, baik pada manusia, hewan, maupun tumbuhtumbuhan. Pernikahan juga suatu cara yang dipilih Allah sebagai jalan bagi manusia untuk beranak, berkembang biak, dan kelestarian hidupnya setelah masing-masing pasangan siap melakukan peranannya yang positip dalam mewujudkan tujuan pernikahan. (Sabiq, 1990: 1)

Tujuan pernikahan yang sejati dalam Islam adalah pembinaan akhlak manusia dan memanusiakan manusia sehingga hubungan yang terjadi antara dua gender yang berbeda dapat membangun kehidupan baru secara sosial dan kultural. Hubungan dalam bangunan tersebut adalah kehidupan rumah tangga dan terbentuknya generasi keturunan manusia yang memberikan kemaslahatan bagi masa depan masyarakat dan negara. (Saebani, 2009: 19-20)

Dengan melakukan pernikahan seseorang akan terhindarlah dari godaan setan, baik godaan dari penglihatan mata maupun alat kelamin atau syahwat. Pernikahan juga bisa dimaknai sebagai ikatan lahir batin antara seorang wanita dengan seorang pria sebagai pasangan suami istri dengan tujuan membentuk keluarga (rumah tangga) yang bahagia dan kekal. Secara khusus tujuan pesrnikahan adalah mewujudkan pribadi-pribadi yang tentram dan damai yang dilandasi oleh cinta dan kasih sayang seperti firman Allah

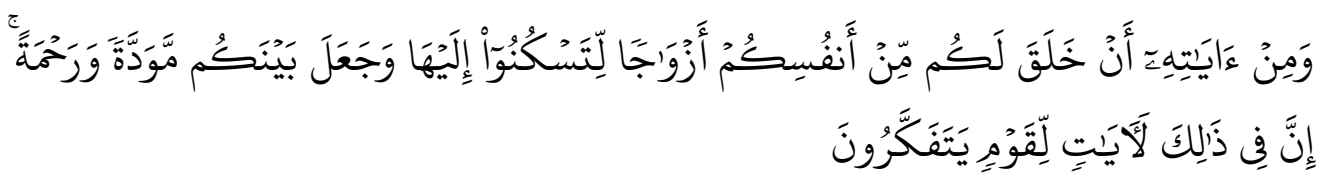

Dan di antara tanda-tanda kekuasaan-Nya ialah Dia menciptakan untukmu isteri-isteri dari jenismu sendiri, supaya kamu cenderung dan merasa tenteram kepadanya, dan dijadikan-Nya di antaramu rasa kasih dan sayang. Sesungguhnya pada yang demikian itu benar-benar terdapat tanda-tanda bagi kaum yang berfikir. (Q.S. Ar-Rum, 30: 21)

Rasulullah memerintahkan untuk menikah dengan orang yang kita senangi dengan memberikan berapa pertimbangan di antaranya: hartanya, kecantikannya, keturunannya, dan terutama dalam pertimbangan masalah agamanya. Karena Islam sangat mempedulikannya hal tersebut untuk mencapai kedalam bahtera rumah tangga yang baik dan harmonis. (Lukman, 2013: 02)

Di era modern pergaulan pria wanita telah melampaui batas suku, etnisitas, kebangsaan, kebahasaan bahkan batas keagamaan. Itu berarti perbedaan-perbedaan tersebut bukan halangan dalam perkenalan dan 
akhirnya menikah. Bagi umat Islam pernikahan beda suku, etnis dan bangsa tidak menjadi halangan, sepanjang kedua belah pihak sama sama beragama Islam.

Manusia yang diberi berbagai kelebihan dari makhluk lainnya, hingga mereka menjadi subjek yang memiliki hak menentukan pilihannya, dan karenanya pula manusia diberi tanggung jawab atas segala tindakannya. Bagi manusia pernikahan merupakan sunnatullah yang amat penting. Demi menjaga martabat kemanusiaannya, maka diberikan Allah ketentuan-ketentuan yang mengatur hubungan antara dua jenis manusia yang berbeda. Dihadirkan para Rasul Allah dengan membawa agama untuk Mengatur manusia tadi. Di sinilah nilai sakral dari suatu pernikahan yang menempatkan manusia pada proporsi yang dikehendaki Allah, yaitu dalam kerangka pengabdi kepadanya.

Di Era modern sekarang marak terjadi peraktek pernikahan beda agama, terutama di Indonesia sebagai contohnya pada tahun 70-an dunia Selebritis dihebohkan oleh pernikahan artis Emalia Contessa dengan Rio Tambunan. Emilia yang beragama Islam bersuamikan seorang Kristen. Pada tahun 80-an Jamal Mirdad yang beragama Islam menikahi Lydia Kandow, seorang artis beragama Kristen. Jauh sebelum kedua pasangan beda agama ini menikah, banyak pasangan beda agama yang melangsungkan pernikahan. Ketika Hak Azasi Manusia begitu digembar-gemmborkan, pernikahan semacam ini terus berlangsung, bahkan ada kecenderungan semakin meningkat. Akhir-akhir ini kasus pernikahan Nia Zulkarnaen yang beragama Islam yang dinikahi pria non muslim, juga mencuat. Ini hanya salah satu dari sekian banyak kasus yang terjadi. Suatu realitas yang terus muncul di tengah-tengah masyarakat heterogen. Beragam suku, ras, adat istiadat bahkan agama. Pernikahan beda agama adalah sesuatu yang amat peka bahkan pada tahun delapan puluhan dipandang sebagai sesuatu yang sangat merisaukan ummat Islam". (Nasruddin, 2001: 23) Peka karena menyangkut agama sebagi sesuatu yang absolut. Kebenaran agama adalah kebenaran absolut Untuk agama dan kebenarannya manusia bersedia berkorban apa saja miliknya, bahkan dengan senang hati dan bergembira hingga meninggal dunia.

Dengan adanya persoalan demikian, perlu adanya pengambilan kesimpualan hukum (istimbath hukum) yang berkaitan dengan pernikahan beda agama. Karena memang tidak memungkinkan sekali menyatukan dua orang yang berbeda agama, sebab masing-masing dari mereka akan beranggapan agama yang yang paling benar adalah agama yang mereka anut. Di samping itu jika memang terjadi pernikan lintas agama lantas ketika akad nikah, agama mana yang akan dipakai. Ini sebenarnya permasalahan mendasar yang harus kita pertimbangkan bersama agar 
prosesi yang sakral dalam hidup kita dan untuk nanti kedatangannya benarbenar mendapatkan restu dari agama.

Berdasarkan uraian di atas maka penulis merasa perlu untuk membahas secara lebih mendalam mengenai permasalahan penikahan beda agama dengan cara mengemukakan sebuah hukum dan meneliti salah satu pendapat ulama atau ahli hukum yang berpendapat tentang pernikahan beda agama. Dengan demikan skripsi ini diberi judul "Pendapat Muhammad Karsayuda tentang pernikahan beda agama".

\section{LANDASAN TEORITIS}

Konsep Nikah

Nikah atau pernikahan dalam literatur fiqh berbahasa Arab disebut dengan dua kata yaitu nikah dan zawaj. Kedua kata ini banyak terdapat dalam Al-Qur'an maupun Al-Hadits.

Secara etimologi nikah berarti bergabung (adh-dham), akad (akad), atau hubungan kelamin (al-wath'u). Adanya dua kemungkinan arti ini karena nikah yang terdapat dalam Al-Qur'an memang mengandung dua arti, (Syarifuddin, 2009: 36) yaitu pada surat Al-Baqarah ayat 230:

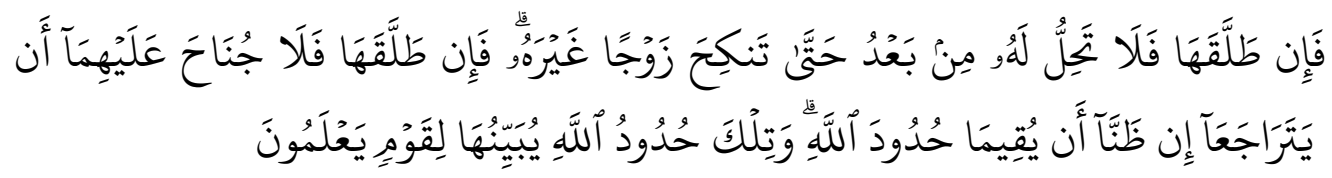

Kemudian jika si suami mentalaknya (sesudah talak yang kedua), maka perempuan itu tidak lagi halal baginya hingga dia kawin dengan suami yang lain. (Q.S. Al-Baqarah, 2: 230)

Para ulama telah berbeda pendapat memaknai lafad nikah dalam makna yang sebenarnya. Imam Syafi'i menyatakan pengertian nikah secara syar'i dari sisi hakiki bermakna akad, sedang dari sisi majazi bermakna hubungan intim. Sedangkan Abu Hanifah menuturkan nikah secara hakiki bermakna hubungan intim dan secara majazi bermakna akad. Pengertian ini mendekati definisi nikah dari segi bahasa. (Zuhaili, 2010: 359-50)

Ulama golongan Hanabilah berpendapat bahwa penunjukkan kata nikah untuk dua kemungkinan tersebut adalah dalam arti sebenarnya sebagaimana terdapat dalam ayat di atas. (Syarifuddin, 2009: 37)

Secara terminologis sebagaiamana yang disebutkan oleh Dr. Ahmad Ghandur, (Syarifuddin, 2009: 39) pernikahan adalah: Akad yang menimbulkan kebolehan bergaul antara laki-laki dan perempuan dalam tuntutan naluri kemanusiaan dalam kehidupan, dan menjadikan untuk kedua pihak secara timbal balik hak-hak dan kewajiban. 
Adapun tujuan pernikahan sebagaimana dalam Pasal 1 UU No. 1 tahun 1974 tentang pernikahan dikatakan pernikahan merupakan ikatan lahir batin antara seorang pria dengan wanita sebagai suami istri dengan tujuan membentuk keluarga (rumah tangga) yang bahgaia dan kekal berdasarkan Ketuhanan Yang Maha Esa. (Aninomous, 2007: 89-90).

\section{a. Dasar Hukum Nikah}

Pernikahan merupakan sunnah Allah dan Rasulnya. Dikatakan sunnah Allah sebab dalam Al-Qur'an terdapat banyak perintah untuk menikah, sedangkan dikatakan sunnah Rasul sebagamana telah diketahui nabi memnuhi hidupnya dengan menikah dan membina rumah tangga. Di antara perintah menunaikan perintah adalah sebagai berikut:

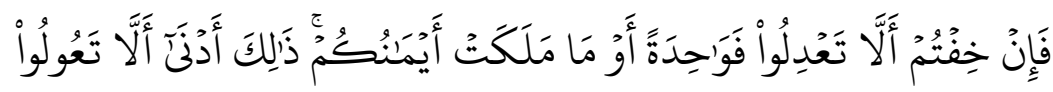

Maka kawinilah wanita-wanita (lain) yang kamu senangi: dua, tiga atau empat (Q.S. Al-Nisa, 4:3) (Departemen Agama RI, 2000: 12)

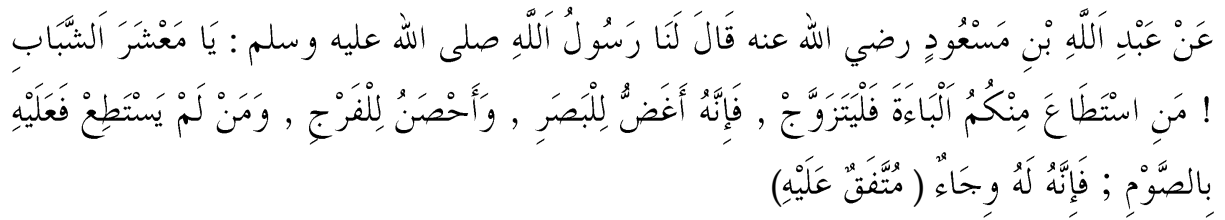

Abdullah Ibnu Mas'ud ra. berkata: Rasulullah Saw. bersabda pada kami: Wahai generasi muda, barangsiapa di antara kamu telah mampu berkeluarga hendaknya ia kawin, karena ia dapat menundukkan pandangan dan memelihara kemaluan. Barangsiapa belum mampu hendaknya berpuasa, sebab ia dapat mengendalikanmu. (muttafaq 'alaih) (Al-Asqalani, 1997: 482)

Syarifudin (2009: 37) mengatakan bahwa hukum asal pernikahan adalah mubah jika dilihat dari hakikat pernikahan merupakan akad yang membolehkan laki-laki dan perempuan sesuatu yang sebelumnya tidak dibolehkan.

Dikarenakan ada tujuan mulia yang ingin dicapai dari pernikahan tersebut dan yang melakukan pernikahan tersebut berbeda pula kondisinya serta situasi yang melingkupi suasana pernikahan itu berbeda pula, maka hukum nikah untuk perorangan bisa berbeda-beda.

Adapun rinciannya adalah sebagai berikut:

1) Wajib, yaitu bagi orang-orang yang telah mampu, berkeinginan menikah dan memiliki perlengkapan nikah, serta ia takut jika terjermus kedalam zina kalau tidak menikah. 
2) Sunah, yaitu bagi orang yang telah mampu tetapi ia masih bisa mengemdalikan dirinya dari perbuatan haram. Dalam hal ini maka sebaiknya ia menikah dari pada membujang.

3) Mubah, yaitu bagi orang yang tidak ada halangan untuk menikah dan dorongan untuk menikah belum membahayakan dirinya. Maka ia belum wajib nikah dan tidak haram jika tidak menikah.

4) Makruh, bagi orang yang mampu menikah namun ia merasa akan curang jika melakukannya.

5) Haram, bagi orang yang tahu bahwa dirinya tidak mau untuk melaksanakan hidup berumah tangga, serta melaksanakan kewajiban lahir dan batinnya. (Alhamdani, 1985: 20)

b. Rukun dan Syarat Nikah

Perbedaan antara syarat dan rukun pernikahan ialah rukun merupakan sebagian dari hakikat pernikahan, di mana pernikahan tidak akan terjadi jika rukun tersebut tidak ada. Sedangkan syarat merupakan sesuatu yang mesti ada dalam pernikahan, tetapi bukan termasuk salah satu yang harus ada dalam pernikahan. (Yunus, 1977: 15) Terdapat dua macam syarat, yaitu ada yang berkaitan dengan rukun di mana syarat tersebut berlaku untuk setiap unsur yang menjadi rukun. Ada pula syarat yang berdiri sendiri yang tidak berlaku untuk kriteria unsur-unsur rukun. (Syarifuddin, 2009: 37)

Rukun-rukun dari pernikahan dalam Islam terdiri dari mempelai laki-laki, mempelai perempuan, wali, saksi, dan akad. Adapun syaratsyaratnya adalah sebagai berikut:

1) Kedua mempelai: Jelas identitasnya dan beragama Islam, antara keduanya tidak terlarang mealangsungkan pernikahan, kedua belah pihak telah setuju untuk melakukan pernikahan, serta keduanya telah mencapai usia yang layak untuk melangsungkan pernikahan. (Syarifuddin, 2006: 64, 66)

2) Wali: Laki-laki, muslim, baligh, berakal sehat, tidak dalam pengampuan, tidak dipaksa, adil, dan tidak sedang melaksanakan ihram. (Alhamdani, 1985: 30)

3) Saksi: Berjumlah minimum dua orang laki-laki, muslim, baligh, berakal sehat, tidak dalam pengampuan, tidak dipaksa, adil, tidak sedang melaksanakan ihram, serta bisa melihat dan mendengar. (Alhamdani, 1985: 30)

4) Akad: Harus terdiri dari ijab dan qabul, materi yang diucapkan dalam ijab dan qabul tidak boleh berbeda, antara ijab dan qabul harus diucapkan secara bersambung tanpa terputus waalaupun sesaat, akad tidak boleh 
dibatasi dengan waktu berlangsungnya pernikahan, serta akad harus menggunakan lafadz yang jelas dan terang. (Syarifuddin, 2006: 62)

Sebagaimana dijelaskan mengenai syarat-syarat pernikahan di atas, dalam syarat pertama disebutkan bahwa kedua mempelai harus beragama Islam. Lalu bagaimana jika terjadi pernikahan antara orang-orang yang berlainan agama seferti si calon suami beragama Islam sedangkan si calon isteri beragama kristen, begitupun sebaliknya. Pernikahan ini disebut dengan pernikahan beda agama.

Pernikahan Beda Agama

Pernikahan beda agama adalah pernikahan yang dilakukuan antara orang yang berlainan agama, yang salah satu beragama Islam dan salah satu lainnya beragama selain dari agama Islam. Agama lain yang dimaksud ialah musyrik dan agama ahlul kitab atau penganut agama selain agama Islam yang mempunyai kitab suci yang dipercayai.

Dan pernikahan beda agama ini pun banyak disinggung dalanm Alquran, yang di dalamnya terdapat adanaya larangan dan suatu kebolehan untuk melangsungkan pernikahan beda agama hanya kepada golongan tertentu yang ada dalam al-Quran yang menimbulkan berbagai pendapat.

Istilah perbedaan agama atau ikhtilaf al-din dijumpai pada pasal 61 KHI "Tidak sekufu dapat dijadikan alasan untuk mencegah pernikahan, kecuali tidak sekufu karena perbedaan agama atau ikhtilaf al-din".(Departemen Agama RI., 1992/1993: 39) Di samping itu didapati pula yang memiliki padanan kata dengan kata lain yaitu dengan kata orang yang tidak beragama Islam (non muslim). Ini terdapat dalam pasal $40 \mathrm{KHI}$ menyebutkan "Dilarang melangsungkan pernikahan antara seorang pria dengan seorang wanita yang tidak beragama Islam; pereceraian dapat terjadi karena peralihan agama atau murtad...," (Departemen Agama RI., 1992/1993: 32) Dengan demikian terlihat bahwa pengertian pernikahan beda agama di sini adalah pernikahan yang dilakukan oleh seorang muslim baik pria maupun wanitanya dengan penganut agama lain (non muslim) secara keseluruhan, tanpa terkecuali pria dan wanitanya berasal dari agama yang mana. Misalnya pernikahan yang dilakukan oleh seorang muslim dengan penganut agama Kristen Protestan, atau seorang muslim dengan seorang penganut agama Budha, dan yang lainnya. Sedangkan pernikahan antara non muslim dengan non muslim lainnya tidak ada disinggung oleh Kompilasi Hukum Islam. Hal ini terjadi, karena Kompilasi Hukum Islam hanyalah mengatur tentang ketentuan yang berlaku bagi orang Islam saja.

\section{Aturan Tentang pernikahan Beda Agama}

Ada beberapa aturan yang dijadikan pegangan oleh orang atau kelompok yang membolehkan dan yang tidak membolehkan pernikahan beda agama yaitu: 


\section{1) Al-Qur'an}

Dalam Al-Qur'an terdapat beberapa ayat-ayat yang menjelaskan tentang pernikahan beda agama di antaranya

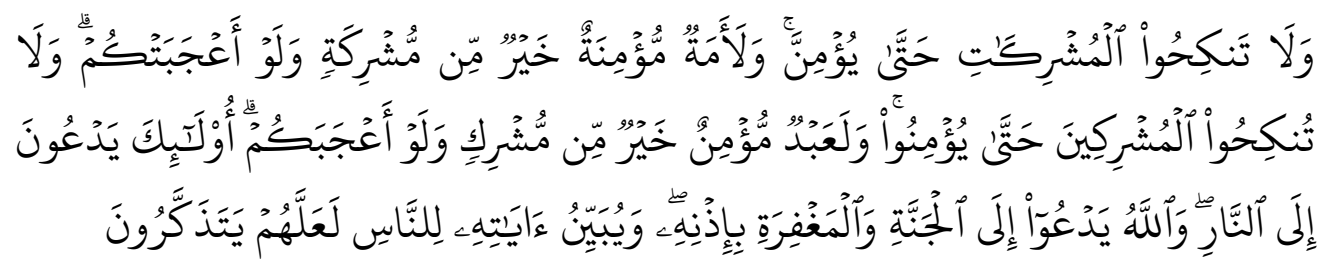

Dan janganlah kamu menikahi wanita-wanita musyrik, sebelum mereka beriman. Sesungguhnya wanita budak yang mukmin lebih baik dari wanita musyrik, walaupun Dia menarik hatimu. dan janganlah kamu menikahkan orang-orang musyrik (dengan wanita-wanita mukmin) sebelum mereka beriman. Sesungguhnya budak yang mukmin lebih baik dari orang musyrik, walaupun Dia menarik hatimu. mereka mengajak ke neraka, sedang Allah mengajak ke surga dan ampunan dengan izin-Nya. dan Allah menerangkan ayat-ayat-Nya (perintah-perintah-Nya) kepada manusia supaya mereka mengambil pelajaran. (Q.S. Al Baqarah, 4:221)

Dalam menafsiri ayat tersebut Oemar Bakri (1982:65) menyatakan dilarang mengawini wanita-wanita musyrik betapapun cantiknya, begitu juga dilarang menikahkan wanita-wanita muslim kepada laki-laki musyrik yang betapapun hebatnya, jangan sampai terbawa hanyut oleh rayuan dan tipu daya kaum musyrikin yang membawa ke neraka. Hendaklah ingat dan bertaqwa kepada Allah yang menunjukkan jalan lurus ke surga.

2) Hadist

Ada beberapa hadist yang menerangkan tentang pernikahan beda agama, yaitu:

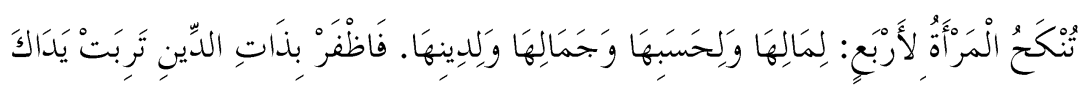

Dari Abu Hurairah r.a. Rasulullah SAW bersabda: Wanita dikawini karena empat hal: karena harta bendanya, karena status sosialnya, karena keindahan wajahnya, karena ketaatannya kepada agama. Pilihah wanita yang taat kepada agama,maka kamu akan bahagia. (H.R. Bukhari). (shahih Bukhori, t.t.: 10)

Berdasarkan hadist tersebut, menurut Ibnu Hamzah, perempuan itu dinikahi karena faktor-faktor kebaikan dan ketaqwaannya, karena kekayaan material dan kecantikannya. Maka Nabi menyuruh faktor mana saja yang disukai. Akan tetapi yang (taat) beragama adalah yang paling penting terpenuhi oleh wanita itu, meskipun ia kaya, atau miskin, dan keduannya (calon suami istri) bertahan (rumah tanggaya) bila faktor agama tidak diindahkan. 


\section{3) Pendapat Para Fuqoha'}

Dikalangan fuqoha' semua madzhab sepakan bahwa Mengenai masalah ini, Islam membedakan hukumnya (Zuhdi, 1987: 4-10) sebagai berikut: Pernikahan antar seorang pria muslim dengan wanita musyrik; Pernikahan antar seorang pria muslim dengan wanita Ahlul Kitab; Pernikahan antara seorang wanita muslimah dengan pria non-muslim.

1) Pernikahan antara seorang pria Muslim dengan wanita musyrik

Islam melarang pernikahan antara seorang pria muslim dengan wanita musyrik, berdasarkan firman Allah dalam Surat Al-Baqarah ayat 221:

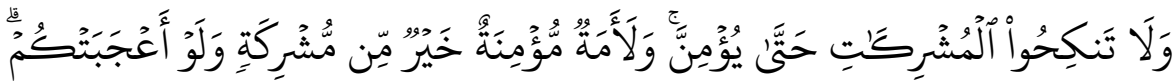

Janganlah kamu mengawini wanita-wanita musyrik, sebelum mereka beriman. Sesungguhnya wanita budak yang beriman lebih baik daripada wanita musyrik, walaupun dia menarik hatimu. (Q.S. Al-Nisa, 4: 221)

Salah satu asbab ayat tersebut di turunkan yaitu pada suatu ketika Ibnu Abi Murtsid Al Chanawi memohon izin kepada Nabi Muhammad agar dia diizinkan menikah dengan seorang wanita musyrik yang cantik dan amat terpandang. Rasulullah belum dapat menjawab walaupun telah dua kali ditanya. Sesudah Rasulullah berdo'a kepada Allah, maka turunlah ayat tersebut. (Ramulyo,1990: 35)

Hanya di kalangan ulama timbul beberapa pendapat tentang siapa musyrikah (wanita musyrik) yang haram dikawini itu. Menurut Ibnu Jarir al-Thabari, seorang ahli tafsir, bahwa musyrikah yang dilarang untuk dikawini itu ialah musyrikah dari bangsa Arab saja, karena bangsa Arab pada waktu turunnya Al-Qur'an memang tidak mengenal kitab suci dan mereka menyembah berhala. Maka menurut pendapat ini, seorang muslim boleh kawin dengan wanita musyrik dari bangsa non-Arab, seperti wanita Cina, India dan Jepang, yang diduga dahulu mempunyai kitab suci atau serupa kitab suci, seperti pemeluk agama Budha, Hindu, Konghucu, yang percaya pada Tuhan Yang Maha Esa, percaya adanya hidup sesudah mati, dan sebagainya.

Tetapi kebanyakan ulama berpendapat, bahwa semua musyrikah baik dart bangsa Arab ataupun bangsa non-Arab, selain Ahlul Kitab, yakni Yahudi (Yudaisme) dan Kristen tidak boleh dikawini. Menurut pendapat ini bahwa wanita yang bukan Islam, dan bukan pula Yahudi atau Kristen tidak boleh dikawini oleh pria muslim, apa pun agama ataupun kepercayaannya, seperti Budha, Hindu, Konghucu, Majusi/Zoroaster, karena pemeluk agama selain Islam, Kristen, dan Yahudi itu termasuk kategori "musyrikah".

Alasan kenapa pria muslim dilarang menikahi wanita musyrik yaitu karena syirik merupakan perbuatan dosa yang tidak bisa diampuni dan 
surga diharamkan bagi orang yang melakukannya. Sekaligus membatalkan amal ibadah yang dikerjakannya disebabkan ketidak ikhlasnya dan karena berazam kepada selain Allah, maka bagaimana mungkin seseorang akan menikahi seorang musyrik untuk menjadi pendamping hidupnya sedangkan prinsip hidup yang dijalaninya sudah sangat jauh berbeda. (Al Jarjani, t.t.: 48)

2) Pernikahan antara seorang pria muslim dengan wanita Ahlul Kitab

Kebanyakan ulama berpendapat, bahwa seorang pria muslim boleh kawin dengan wanita Ahlul Kitab (Yahudi atau Kristen), berdasarkan firman Allah dalam Surat Al-Maidah ayat 5:

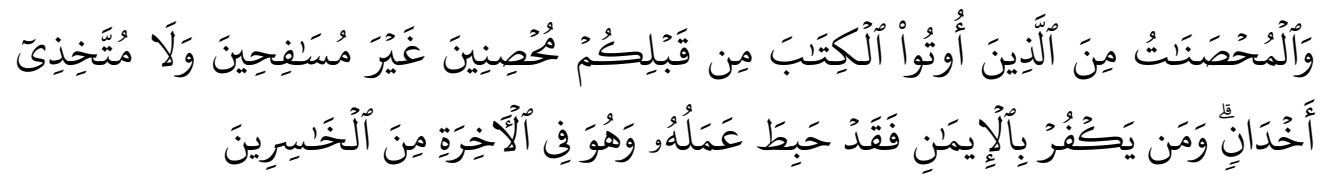

dan wanita-wanita yang menjaga kehormatan di antara orang-orang yang diberi kitab suci sebelum kamu. (Q.S. Al-Maidah, 5:5) (Departemen Agama RI, 2000:28)

Selain berdasarkan Al-Qur'an surat Al-Maidah ayat 5, juga berdasarkan sunah Nabi, di mana Nabi pernah kawin dengan wanita Ahlul Kitab, yakni Mariah Al-Qibtiyah (Kristen). Demikian pula seorang Sahabat Nabi yang termasuk senior bernama Hudzaifah bin Al-Yaman pernah kawin dengan seorang wanita Yahudi, sedang para Sahabat tidak ada yang menentangnya. Di antara Sahabat lain ada pula yang kawin dengan Ahli Kitab, seperti Utsman bin Affan mengawini Na'ilah binti al-Gharamidah seorang wanita beragama Nasrani yang kemudian masuk Islam, Jabir pernah ditanya tentang pernikahan pria muslim dengan wanita Yahudi atau Nasrani, beliau menjawab: kamipun pernah menikah dengan mereka pada waktu penaklukan Kufah bersama-sam dengan Sa'ad bin Abi Waqash.(Rasyid, 1367: 180)

Kemudian dikalangan Jumhur Ulama yang membolehkan kawin dengan Ahli Kitab, juga berbeda pendapat (Hasan, 1996: 12), yaitu:

a. Sebagian Madzhab Hanafi, Maliki, Syafi'i, dan Hambali mengatakan bahwa hukum pernikahannya itu makruh

b. Menurut pendapat sebagian Madzhab Maliki, Ibnul Qosim, Khalil bahwa pernikahannya itu diperbolehkan secara mutlak dan ini merupakan pendapat Malik.

c. Az-zarkayi (madzhab Syafi'i) mengatakan bahwa pernikahan itu di sunatkan apabila wanita Ahli Kitab itu diharapkan dapat masuk Islam. Ini bersandarkan pada pernikahan Utsman bin Afan dengan Nailah.

Namun demikian, ada sebagian ulama yang melarang pernikahan antara seorang pria Muslim dengan wanita Kristen atau Yahudi, karena 
pada hakikatnya doktrin dan praktek ibadah Kristen dan Yahudi itu mengandung unsur syirik yang cukup jelas, misalnya ajaran trinitas dan mengkultuskan Nabi Isa dan ibunya Maryam (Maria) bagi umat Kristen, dan kepercayaan Uzair putra Allah dan mengkultuskan Haikal Nabi Sulaiman bagi umat Yahudi.

Salah satu golongan yang melarang menikah dengan Ahli Kitab Yaitu Golongan Syi'ah, mereka berlandaskan firman Allah dalam surat AlBaqarah, 2: 221)

Golongan ini berpendapat, bahwa wanita-wanita Ahli Kitab itu termasuk kafir, karena wanita-wanita Ahli Kitab itu telah musyrik (menyekutukan Allah) berdasarkan riwayat Ibnu Umar, bahwa beliau pernah ditanya tentang hukum mengawini wanita Yahudi dan Nasrani. Beliau menjawab: "sesungguhnya Allah mengharamkan Wanita-wanita musyrik bagi orang-orang mukmin, saya tidak mengetahui kemusyrikan yang lebih besar dari pada anggapan seorang wanita (Nasrani), bahwa Tuhannya adalah Isa. Padahal Isa hanya seorang manusia hamba Allah. (Hasan, 1996: 12)

3) Pernikahan antara seorang wanita muslimah dengan pria non-muslim

Ulama telah sepakat, bahwa Islam melarang pernikahan antara seorang wanita muslimah dengan pria non-muslim, baik calon suaminya itu termasuk pemeluk agama yang mempunyai kitab suci, seperti Kristen dan Yahudi ataupun pemeluk agama yang mempunyai kitab serupa kitab suci, seperti Budhisme, Hinduisme, maupun pemeluk agama atau kepercayaan yang tidak punya kitab suci dan juga kitab yang serupa kitab suci. Termasuk pula di sini penganut Animisme, Atheisme, Politeisme dan sebagainya.

Firman tersebut mengingatkan kepada umat Islam, hendaknya selalu berhati-hati dan waspada terhadap tipu muslihat orang-orang kafir termasuk Yahudi dan Kristen, yang selalu berusaha melenyapkan Islam dan umat Islam dengan berbagai cara. Dan hendaknya umat Islam tidak memberi jalan/kesempatan kepada mereka untuk mencapai maksudnya. Misalnya dengan jalan pernikahan seorang wanita Islam dengan pria nonMuslim.

\section{METODE PENELITIAN}

Sesuai dengan karakteristik masalah, tujuan dan kerangka pemikiran penelitian, metode yang digunakan dalam penelitian ini adalah penelitian deskriptif analisis. Penelitian deskriptif bertujuan untuk mendeskripsikan apa-apa yang saat ini berlaku. Di dalamnya terdapat upaya mendeskripsikan, mencatat, analisi, dan menginterpretasikan kondisikondisi yang sekarang terjadi atau ada. Penelitian ini hanya 
mendeskripsikan informasi apa adanya sesuai variable-variabel yang diteliti. (Mardalis, 1993: 26)

Sedangkan analisis adalah upaya menguraikan atau memisahmisahkan data oleh peneliti sehingga berdasarkan data dapat ditarik pengertian serta kesimpulan-kesimpulan. (Abdurrahman, 2003: 65)

Dengan demikian metode deskriptif analisis bertujuan untuk mendeskripsikan beserta menganalisis suatu data untuk ditarik kesimpulankesimpulannya.

\section{HASIL PENELITIAN DAN PEMBAHASAN}

Biografi Muhammad Karsayuda

Muhammad Karsayuda, adalah seorang yang dilahirkan dari pasangan suami-istri Buseri dan Sundiyah pada tanggal 05 Agustus Tahun 1954 di desa Mahang Kecamatan Barabai Kabupaten Kalimantan Selatan, dan anak keempat dari pasangan tersebut. Nama itu diberikan kepadanya untuk mengenang keturunan mereka terdahulu bernama Yudhakarsa, tokoh di daerah mahang (kini masuk wilayah Kabupaten Hulu Sungai Tengah) yang dikenal kharismatik, tangguh dan giat melawan penjajah di masanya.

Muhammad Karsayuda memiliki seorang Isteri yang bernama Hj.Rusdiniyah Syamsuddin dan dari hasil pernikahannya tersebut di karuniai anak yang bernama M.Rifqinizamy Karsayuda dan Widya Ais Sahla Karsa. Dikenal sebagai sosok pejuang, di mata anak, istri dan rekan sepergaulannya. Karena sadar bahwa berasal dari seorang anak yang dilahirkan dari keluarga petani dengan kadar ekonomi pas-pasan, akan tetapi tidak membuat patah semangat dengan kegigihannya mencoba berjuang meraih pendidikan setinggi-tingginya.

Mengawali karier pendidikannya di Sekolah Dasar Negri Mahang lulus pada tahun 1966, kemudian melanjutkan pendidikan di Sekolah Tinggkat Pertama Dan Sekolah Menengah Atas di madrasah Muallimin Barabai lulus tahun 1971, sebelum menginjakkan kakinya di bangku kuliah selama Dua tahun menjadi Santri di Pondok pesantrean Ibnu Amin Pamangkih Barabai (1972-1974). Ketika sudah melanjutkan ke perguruan tinggi di Institut Agama Islam Negeri Antasari Banjarmasin pada tahun 70an dan mengambil jurusan Fakultas Syari'ah kemudian meraih gelar Sarjana muda pada tahun 1977. Pada saat itu sebuah gelar Sarjana adalah Sesuatu yang sangat langka di antara kerabat, bahkan rekan-rekan sekampungnya masa itu. (Karsayuda, 2006: 264) 
Latar Belakang Lahirnya Pemikiran Muahmmad Karsayuda Mengenai Hukum Pernikahan Beda Agama

Adapun yang melatar belakangi lahirnya pemikiran Muahmmad Karsayuda mengenai hukum pernikahan beda agama adalah sebagai berikut:

a. Kondisi Masyarakat di Indonesia

Masyarakat Indonesia merupakan masyarakat yang majemuk, khususnya bila dilihat dari segi etnis/suku bangsa dan agama. Konsekuensinya, dalam menjalani kehidupannya masyarakat Indonesia dihadapkan kepada perbedaan-perbedaan dalam berbagai hal, mulai dari kebudayaan, cara pandang hidup dan interaksi antar individunya. Keadaan masyarakat Indonesia yang majemuk menjadikan pergaulan di masyarakat semakin luas dan beragam, hal ini telah mengakibatkan pergeseran nilai agama yang lebih dinamis daripada yang terjadi pada masa lampau, seorang muslimin dan muslimat sekarang ini lebih berani untuk memilih pendamping hidup non-muslim. Hal ini tentu saja dianggap oleh masyarakat kita yang mayoritas beragama Islam sebagai penyalahan atau pergeseran nilai-nilai Islam yang ada. Tak jarang hal ini sering menimbulkan gejolak dan reaksi keras di kalangan masyarakat kita. Masalah ini menimbulkan perbedaan pendapat dari dua pihak pro dan kontra, masing-masing pihak memiliki argumen rasional maupun argumen logika yang berasal dari penafsiran mereka masing-masing terhadap dalildalil Islam tentang pernikahan beda agama. (Karsayuda, 2006: 3-5)

b. Terdapat Perbedaan Penetapan Hukum Antara Kompilasi Hukum Islam dan Sumber Hukum Islam (Al qur'an dan Hadits) Tentang Pernikahan Beda Agama

Alasan kedua mengenai latar belakang lahirnya pemikiran tersebut, adalah di Indonesia sendiri terdapat perbedaan penetapan hukum mengenai penikahan beda agama, yaitu antara KHI dan Sumber Hukum Islam untuk penjelasan lebih rinci sebagai berikut:

1) Firman Allah Dalam Surat Al-Maidah ayat 5 :
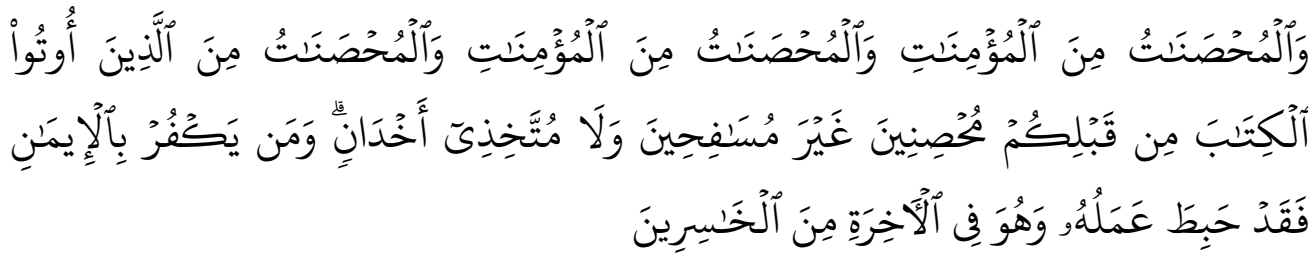

Dan dihalalkan mengawini wanita-wanita yang menjaga kehormatan di antara wanita-wanita yang beriman dan wanita-wanita yang menjaga kehormatan di antara orang-orang yang diberi kitab suci sebelum kamu. (Q.S. Al-Maidah, 5: 5) (Departemen Agama RI, 2000: 27) 
Sebagaimana tertera dalam ayat di atas bahwa Al qur'an telah menghalalkan mengawini wanita-wanita selain yang seiman (beragama Islam) yaitu membolehkan dengan seorang Ahlul Kitab.

2) Sunah Nabi

Nabi pernah melaksanakan sendiri dengan menikahi seorang wanita Ahlul Kitab, yakni Mariah Al-Qibtiyah (Kristen). Demikian pula seorang Sahabat Nabi yang termasuk senior bernama Hudzaifah bin AlYaman pernah kawin dengan seorang wanita Yahudi, sedang para Sahabat tidak ada yang menentangnya.Di antara Sahabat lain ada pula yang kawin dengan Ahli Kitab, seperti Utsman bin Affan mengawini Na'ilah binti alGharamidah seorang wanita beragama Nasrani yang kemudian masuk Islam, Jabir pernah ditanya tentang pernikahan pria muslim dengan wanita Yahudi atau Nasrani, beliau menjawab: kamipun pernah menikah dengan mereka pada waktu penaklukan Kufah bersama-sam dengan Sa'ad bin Abi Waqash. (Rasyid, 1367: 180)

3) Kompilasi Hukum Islam (KHI)

Dalam KHI terdapat aturan tersendiri mengenai pernikahan beda agama sebagaimana diatur dalam pasal 40 huruf c) KHI yang lengkapnya sebagai berikut: "Dilarang melangsungkan pernikahan antara seorang pria dengan seorang wanita karna keadaan tertentu:

i. Karena wanita yang bersangkutan masih terikat satu pernikahan dengan pria Lain;

ii. Seorang wanita yang masih berada dalam masa iddah dengan pria lain;

iii. Seorang wanita yang tidak beragama Islam". (Departemen Agama RI, 2012: 6)

Dan di dalam pasal 61 yang memuat ketentuan mengenai pencegahan pernikahan, disebutkan: "Tidak sekufu tidak dapat dijadikan alasan untuk mencegah pernikahan, kecuali tidak sekufu karena perbedaan agama atau Ikhtilafu al-Dien". (Departemen Agama RI, 2012: 9)

Karsayuda (2006: 136-141) mengatakan bahwa Kompilasi Hukum Islam mempunyai alasan tersendiri mengenai penetapan hukum pernikahan beda agama antara lain:

c. Beda agama sebagai alasan kekurangan syarat pernikahan

Beda agama yang terjadi dan diketahui sebelum akad nikah oleh Kompilasi Hukum Islam diatur dalam Bab VI mengenai Larangan Kawin, dalam Pasal 40 "Dilarang melangsungkan pernikahan antara seorang pria denagan seorang wanita karena keadaan tertentu: karena wanita yang bersangkutan 
masih terikat satu pernikahan dengan pria lain, seorang wanita yang masih berada dalam masa iddah dengan pria lain, seorang wanita yang tidak beragama Islam", dan 44 "Seorang wanita Islam dilarang melangsungkan pernikahan dengan seorang pria yang tidak beragama Islam.", serta Bab X mengenai Pencegahan Pernikahan, Pasal 61 "Tidak sekufu tidak dapat dijadikan alasan untuk mencegah pernikahan, kecuali tidak sekufu karena perbedaan agama atau ikhtilaafu al dien.". Walau bagian ini secara harfiah terpisah dari ketentuan mengenai rukun dan syarat pernikahan, namun Pasal 18 menjelaskan "Bagi calon suami dan calon isteri yang akan melangsungkan pernikahan tidak terdapat halangan pernikahan sebagaimana diatur dalam bab VI". Bahwa sesungguhnya Bab VI ini memiliki hubungan dengan Bab IV bagian kedua mengenai calon mempelai. (Departemen Agama RI, 2012: 3, 6, dan 9)

Dengan demikian Pasal 40 dan 44 sesungguhnya adalah syarat bagi calon mempelai, walau diungkapkan dalam sebutan larangan dan bukan rukun, kendati kedua calon mempelai itu sendiri adalah rukun nikah.

d. Beda agama sebagai alasan pencegahan pernikahan

Pasal 61 tidak mempunyai konsekuensi bagi absah tidaknya pernikahan, karena tindakan yang dilakukan adalah pencegahan, sehingga tidak terjadi/belum terjadi akad nikah. Pencegahan diajukan kepada Pengadilan Agama dalam daerah hukum dimana pernikahan akan dilangsungkan dengan memberitahukan kepada PPN setempat (Pasal 65). Yang dapat mengajukan pencegahan adalah keluarga dalam garis keturunan kebawah, saudara, wali nikah, wali pengampu dari pihak mempelai (Pasal 62). Suami atau isteri yang masih terikat dalam pernikahan dengan salah satu calon mempelai dapat mengajukan pencegahan pernikahan (Pasal 63). Bahkan pejabat yang bertugas mengawasi pernikahan berkewajiban mencegah pernikahan bila rukun dan syarat pernikahan tidak terpenuhi (Pasal 64). (Karsayuda (2006: 138)

Kompilasi Hukum Islam menempatkan pencegahan pernikahan begitu penting dengan menempatkannya sebagai salah satu kewajiban pejabat yang bertugas mengawasi pernikahan. Hal ini dapat dimengerti karena jika sebuah pernikahan yang cacat terjadi, maka dampaknya tidak sekedar memisahkan dua manusia yang telah terlanjur membangun cintanya dalam sebuah rumah tangga, tetapi bisa melahirkan problem sosial bagi anak yang dilahirkan dari pernikahan tersebut. Amanah KHI kepada pejabat dengan mewajibkan melakukan pencegahan pernikahan yang tidak sesuai dengan hukum Islam memberi jaminan bahwa sebuah pernikahan yang dilakukan dihadapan PPN adalah pernikahan yang sah. Putusan Pengadilan Agama mengenai pencegahan pernikahan belum tentu mengakhiri persoalan. Para pihak sebenarnya dapat mengajukan keberatan, dalam hal ini berarti terjadi sengketa mengenai status keberagamaan calon mempelai. Upaya hukum seharusnya juga terbuka agar para pihak yang 
tidak puas dapat melakukannya. Walau demikian, bukan sama sekali sepi dan persoalan hukum, karena Putusan Pengadilan mengenai pencegahan pernikahan belum tentu mengakhiri persoalan, dan pihak yang tidak puas terhadap putusan Pengadilan Agama mencoba melakukan upaya hukum melalui jalur lain. (Karsayuda (2006:140)

e. Beda agama sebagai alasan pembatalan pernikahan

Pasal 75 (a) bagian dari pasal-pasal yang mengatur tentang pembatalan pernikahan, yang salah satu alasan pembatalannya adalah "salah satu dari suami isteri murtad". (Departemen Agama RI. 2012: 10) Keputusan Pembatalan pernikahan karena alasan salah satu dari suami isteri murtad, tidak berlaku surut. Ketentuan ini mempunyai dampak bahwa sebuah pernikahan yang salah satu pihaknya murtad akan dibatalkan pernikahannya terhitung sejak putusan dijatuhkan. Jadi murtadnya seseorang "tidak otomatis" membuat pernikahannya menjadi batal, ini tetap berlangsung dan dipandang sebagai ikatan pernikahan yang sah sampai ada putusan pengadilan yang tidak boleh berlaku surut. Pada sisi lain Pengadilan baru dapat membatalkan sebuah pernikahan apabila ada permohonan yang diajukan oleh pihak yang berhak - tidak setiap orang yang mengetahui adanya salah satu suami isteri yang murtad berhak mengajukan pembatalan. Yang dapat mengajukan permohonan pembatalan pernikahan menurut Pasal 73 adalah: "Para keluarga dalam garis keturunan lurus ke atas dan kebawah dari suami atau isteri, Suami atau isteri itu sendiri, Pejabat yang berwenang mengawasi pelaksanaan pernikahan menurut undangundang, dan Para pihak yang berkepentingan yang mengetahui adanya cacat dalam rukun dan syarat pernikahan menurut hukum Islam dan Peraturan Perundangundangan sebagaimana tersebut dalam Pasal 67." (Departemen Agama RI, 2012: 10)

Pembatalan pernikahan karena salah satu pihak suami atau isteri murtad tidak termasuk dalam alasan batal" atau dapat dibatalkan"nya suatu pernikahan. Namun dilihat dari "mulai berlakunya" pembatalan yang tidak bisa berlaku surut, maka alasan ini termasuk bagian yang dapat dibatalkan. Batalnya suatu pernikahan dimulai sejak putusan Pengadilan Agama mempunyai kekuatan hukum yang tetap dan berlaku sejak saat berlangsungnya pernikahan (Pasal 74 ayat 2). Alasan lainnya dapat kita lihat pada posisi pejabat yang berwenang mengawasi pelaksanaan pernikahan yang hanya diberi hak, bukan kewajiban, berbeda dengan posisinya dalam kasus pencegahan pernikahan. Karena itu KHI menempatkan batalnya nikah karena murtadnya salah satu pihak pada kemauan pihak yang berhak mengajukan pembatalan. Bagi pejabat yang berwenang mengawasi pelaksanaan pernikahan, dalam hal ini PPN bagi umat Islam, pengajuan pembatalan nikah menjadi tugasnya dalam rangka menjaga dan memelihara demi terlaksanakannya hukum Islam secara baik dan benar. Dalam menjalankan tugasnya ini pejabat tidak dapat mengelak karena alasan biaya 
yang tidak tersedia, karena kepadanya tidak dibebankan biaya perkara. (Mahkamah Agung RI, 2002:234)

Karsayuda menggunakan Konsep hukum mengenai pernikahan beda agama dengan menganailsis perbedaan penetapan hukum antara KHI dan sumber hukum Islam yaitu Al qur'an dan Hadits tentang penikahan beda agama dengan ditinjau dari segi keadilannya. Manakah ketetapan hukum yang sesuai dengan kondisi masyarakat di Indonesia. Tentang konsep hukum dari segi keadilan sebagaimana yang dijelaskan Hans Kelsen (2010: 48) menurutnya keadilan tentu saja juga digunakan dalam hukum, dari segi kecocokan dengan hukum positif-terutama kecocokan dengan undang-undang. Ia menggangap sesuatu yang adil hanya mengungkapkan nilai kecocokan relative dengan sebuah norma "adil" hanya kata lain dari "benar".

Arti dari hukum itu sendiri memiliki kaitannya dengan keadilan sebagaimana menurut Soeroso, (2006: 24-26) secara etimologis arti hukum dapat dilihat kata, yaitu Ius, dan Lex.

1) Hukum

Kata hukum berasal dari bahasa Arab yaitu "hukmun" dan merupakan bentuk tunggal atau mufrod. Kata jamaknya adalah "Ahkam", yang selanjutnya diambil dalam bahasa Indonesia menjadi "Hukum". Di dalam pengertian hukum terkandung pengertian bertalian erat dengan pengertian yang dapat melakukan paksaan.

2) Recht

Recht berasal dari kata "Rectum" (bahasa latin) yang mempunyai arti bimbingan atau tuntutan, atau pemerintahan. Bertalian dengan rectum dikenal juga kata "Rex" yaitu orang yang pekerjaannya memberikan bimbingan atau memerintah. Rex juga dapat diartikan "Raja" yang mempunyai Regimen yang artinya kerajaan. Kata Rectum dapat juga dihubungkan dengan kata "Directum" yang artinya orang yang mempunyai pekerjaan membimbing atau mengarahkan.

Kata Recht atau bimbingan atau pemerintahan selalu didukung oleh kewibawaan. Seorang yang membimbing, memerintah harus mempunyai kewibawaan. Kewibawaan mempunyai hubungan erat dengan ketaatan, sehingga orang yang mempunyai kewibawaan akan ditaati oleh orang lain. Dengan demikian perkataan recht mengandung pengertian kewibawaan dan hukum atau recht itu ditaati orang yang secara sukarela.

Dari kata recht tersebut tumbul istilah "Gerechtigheid". Ini adalah bahasa Belanda atau "gerechtikeit" dalam bahasa Jerman berarti keadilan, sehingga hukum juga mempunyai hubungan erat dengan keadilan. Jadi 
dengan demikian recht dapat diartikan hukum yang mempunyai dua unsur penting yaitu "kewibawaan dan keadilan".

3) Ius

Kata Ius (latin) berarti hukum, berasal dari bahasa latin "Iubere" artinya mengatur atau memerintah. Perkataan mengatur dan memerintah itu mengandung dan berpangkal pokok pada kewibawaan.

Selanjutnya istilah Ius bertalian erat dengan "Iustitia" atau keadilan. Pada jaman dulu bagi orang Yunani Iustitia adalah Dewi keadilan yang dilambangkan sebagai seorang wanita dengan kedua matanya tertutup dengan tangan kirinya memegang neraca dan tangan kanan memegan sebuah pedang. Adapun lambang tersebut mempunyai arti sebagai berikut:

a) Kedua mata tertutup

Ini berarti bahwa di dalam mencari keadilan tidak boleh membedakan terhadap si pelaku. Apakah ia kaya, miskin, mempunyai kedudukan tinggi atau rendah. Dengan singkat dapat dikatakan bahwa di dalam mencari keadilan tidak boleh pandang boleh.

b) Neraca

Ini melambangkan keadilan. Dalam mencari dan menerapkan keadilan harus ada kesamaan atau sama beratnya.

c) Pedang

Adalah perlambangan dari keadilan yang mengejar kejahatan dengan suatu hukum dan dimana perlu dengan hukuman mati.

Jadi secara etimologis, dapat disimpulkan bahwa Ius yang berarti hukum bertalian erat dengan keadilan (Iustitia) yang mempunyai 3 (tiga) unsur: wibawa, keadilan dan tata kedamaian.

d) 4) Lex

Kata Lex berasal dari bahasa latin dan berasal dari kata "Lesere". Lesere memiliki arti mengumpulkan orang-orang untuk diperintah. Jadi di sini terkandung adanya hukum ialah wibawa atau otoritas, sehingga kata Lex yang berarti hukum sangat erat hubungannya dengan perintah dan wibawa. Berdasarkan uraian di atas dan sehubungan dengan arti kata hukum, maka dapat disimpulkan bahwa: (a) Pengertian hukum itu bertalian erat dengan keadilan. (b) Pengertian hukum bertalian erat dengan kewibawaan. (c) Pengertian hukum bertalian erat dengan ketataan/orde yang selanjutnya menimbulkan kedamaian.

Muhammad Karsayuda membagi pembahasan mengenai pernikahan beda agama ke dalam tiga bagian: 
1. Non Muslim dalam Pernikahan

Karsayuda (2006: 75-76) berpendapat ada dua kriteria non muslim dalam pernikahan, yang disebutkan dalam al Qur'an yaitu Ahli Kitab dan musyrik (yang menyerupai Ahli Kitab). Musyrik adalah pihak yang dilarang al Qur'an untuk ditikahi oleh seorang muslim sebagaimana disebutkan dalam Surah al Baqarah ayat 221 di atas dan Surah al Mumtahanah ayat 10.

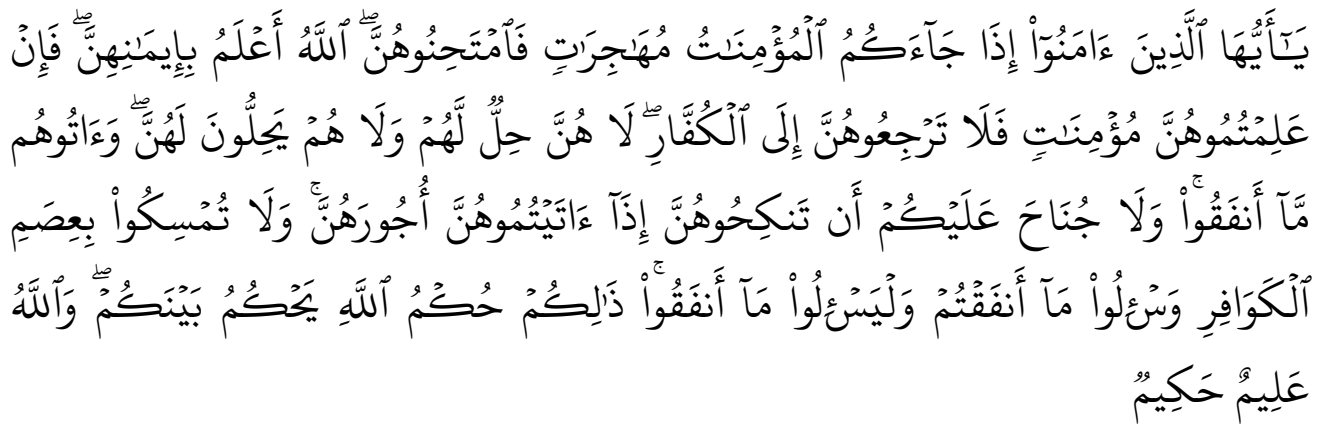

Hai orang-orang yang beriman, apabila datang berhijrah kepadamu perempuan-perempuan yang beriman, Maka hendaklah kamu uji (keimanan) mereka. Allah lebih mengetahui tentang keimanan mereka;maka jika kamu telah mengetahui bahwa mereka (benar-benar) beriman Maka janganlah kamu kembalikan mereka kepada (suami-suami mereka) orang-orang kafir. Mereka tiada halal bagi orang-orang kafir itu dan orang-orang kafir itu tiada halal pula bagi mereka. Dan berikanlah kepada (suami suami) mereka, mahar yang telah mereka bayar. Dan tiada dosa atasmu mengawini mereka apabila kamu bayar kepada mereka maharnya. Dan janganlah kamu tetap berpegang pada tali (pernikahan) dengan perempuan-perempuan kafir; dan hendaklah kamu minta mahar yang telah kamu bayar; dan hendaklah mereka meminta mahar yang telah mereka bayar. Demikianlah hukum Allah yang ditetapkanNya di antara kamu. dan Allah Maha mengetahui lagi Maha Bijaksana. (Q.S. Al Mumtahanah .60: 10) (Departemen Agama RI, 2000: 332)

Walaupun larangan mengawini orang musyrik itu adalah orang musyrik di tanah Arab, karena saat ayat diturunkan tujuannya adalah musyrik tanah Arab, tetapi juga berlaku umum untuk semua orang selain yang beragama Islam dan Ahli Kitab. Sebagaimana pendapat Ibnu Katsir (TT: 257) bahwa yang dimaksud musyrik di sini adalah penyembah berhala, dan dikhususkan (dikeluarkan dari pengertian musyrik) adalah Ahli Kitab. Untuk Ahli Kitab pada masa sekarang (orang Nasrani/Yahudi) mereka digolongkan ke dalam musyrik, seorang muslim dilarang menikah dengannya, terutama muslim di Indonesia, karena agama Nasrani yang di Indonesia sudah menganut ajaran Trinitas. Ajaran itu sendiri menganut konsep tiga Tuhan Yaitu: Tuhan Bapa (Allah), Tuhan Ibu (Maryam), dan 
Tuhan Anak (Nabi Isa). Tentunya ajaran tersebut sudah menyimpang dari ajaran Ahli Kitab sebenarnya yang hanya menyembah kepada satu Tuhan yaitu Allah dan Nabi Isa itu adalah utusan Allah yang dilahirkan dari rahim Siti Maryam.

Dalam kehidupan masyarakat modern yang materialistik, eksistensi dan penilaian terhadap manusia ditentukan oleh kemampuan finansialnya. Makin kuat posisi finansial seseorang, maka makin tinggi status sosialnya. Hal ini terjadi pula dalam kehidupan rumah tangga, sehingga siapa yang paling banyak memberi masukan dana dalam keluarga cenderung menguasai pihak lain. Sebagian ahli tafsir juga mengakui bahwa laki-laki/ suami menjadi pemimpin bagi kaum perempuan (isteri), lantaran pihak suami sebagai pemasok dana bagi keluarga. Sejalan dengan pemikiran ini, maka perempuan kitabiyah yang secara ekonomi lebih kuat dan suaminya yang muslim, berpotensi menjadi memimpin dalam rumah tangga, dalam arti pihak isteri yang mengendalikan dan menentukan kebijaksanaan dalam rumah tangga. Dengan demikian maka apa yang dilarang Al qur'an melalui ayat 51 Surah Al Maidah secara tidak sengaja telah pula dilanggar. (Karsayuda (2006: 80)

\section{Gambaran Tentang Ahli Kitab}

Pendapat Karsayuda (2006: 77) mengenai gambaran tentang Ahli Kitab yang hidup pada masa Rasulullah perlu diketengahkan, mengingat teng gang waktu antara zaman Rasul dengan saat ini sangat jauh, sehingga kemungkinan terjadinya perubahan yang signifikan dalam agama Nasrani sangat dimungkinkan. Apalagi tempat antara tanah Arab dengan bumi Indonesia juga amat jauh, sehingga kemungkinan terjadinya perbedaan kendati dalam waktu yang bersamaan juga dimungkinkan. Sebagaimana diketahui bahwa agama Nasrani pernah mengalami perubahan besar dalam doktrin teologinya dengan adanya dogma trinitas. Untuk mendapat jawaban apakah dogma trinitas itu merubah status ke Ahli Kitaban kaum Nasrani, sehingga mereka tidak boleh lagi dinikahi. Konsilidasi Nikea tahun $325 \mathrm{M}$, dua abad lebih sebelum Rasulullah lahir, sebagai pangkal lahirnya paham trinitas, terjadi dengan latar belakang persengketaan tentang pribadi Al Masih. Dalam konsili yang dicampuri penguasa Konstantine dengan memaksakan kehendak yang bertentangan dengan keesaan Tuhan, disertai dengan pembahauran secara membabi buta terhadap pendapat tokoh agama, walau hal itu bertentangan dengan nash agama masehi.( Abu Zahrah, 1969: 138-143) Secara formal ajaran trinitas itu hadir dalam teologi Nasrani adalah sejak konsili Nikea yang unsur penting dari ajarannya adalah percaya pada tiga oknum.

Kendati jangka waktu antara tumbuh berkembangnya ajaran Trinitas dengan diturunkannya ayat 5 Surah al Maidah berjalan sekitar tiga abad, belum pasti di lingkungan tanah Arab, khususnya kota Madinah, penganut agama Nasraninya telah menganut paham Trinitas. Sebab masih 
ada beberapa faktor yang memungkinkan suatu paham tidak bisa diterima dan tersebar sedemikian rupa. Diakui bahwa jauh sebelum diutusnya Nabi Muhammad SAW telah lenyap sifat-sifat kesucian dan kesederhanaan dari ajaran Nasrani, sehingga agama ini telah menjadi penyembah berhala dan gambar Al Masih. Dalam pertukaran pikiran antara Nabi Muhammad SAW dengan perutusan Masehi tanah Arab dikatakan bahwa keturunan Isa sebagai anak Allah, sebagai Allah sendiri, dan sebagai satu di antara tiga. Perubahan dari ajaran asli bukan saja terjadi pada penganut agama Nasrani, tetapi umat Yahudi pun telah pula mengalami perubahan kitab mereka dengan mengingkari kerasulan Muhammad. (Karsayuda, 2006: 78)

Dapat diketahui bahwa ternyata dogma Trinitas sudah ada dan dianut umat Nasrani di sekitar Rasulullah. Begitu pula umat Yahudi sudah mengalami penyimpangan dari ajaran aslinya. Dengan demikian dapat disimpulkan bahwa keadaan umat Nasrani dan Yahudi yang oleh ayat 5 Surah al Maidah disebut sebagai Ahli Kitab, tidaklah berbeda dengan yang hidup pada masa sekarang, sebab penyelewengan terjadi sejak sebelum Rasulullah diutus, dan terjadi pula di sekitar lingkungan Rasulullah.

pendapat Syafi'iyah yang mu'tamad mensyaratkan Ahli Kitab yang boleh dinikahi memenuhi kriteria "minqablikum", artinya wanita tersebut berasal dan keluarga Nasrani atau Yahudi yang menganut salah satu dari kedua agama tersebut sebelum Nabi Muhammad diutus/diangkat menjadi Rasul (Sesuai ajaran Nabi Isa /Musa). (Karsayuda, 2006:79)

Di Indonesia secara formal hanya ada penganut Nasrani (Katholik dan Protestan), penganut Yahudi secara formal belum dikenal di Indonesia. Walau demikian banyaknya orang Indonesia yang berkiprah di luar negeri lebih memungkinkan terjadinya persentuhan bahkan pernikahan antara seorang muslim Indonesia dengan penganut agama Yahudi. Secara harfiah Yahudi dan Nasrani dipandang sebagai Ahli Kitab, tetapi dalam perkembangan berikutnya setelah kehadiran Islam, namun mereka tetap dalam keyakinan semula. Atau bahkan memasuki agama Yahudi dan Nasrani setelah tersebarnya Islam, tidak lagi dipandang sebagai Ahli Kitab yang boleh dinikahi lelaki muslim, melainkan sebagai orang musyrik yang dilarang menikah dengannya.

3. Pertimbangan Kondisi Masyarakat

Kondisi masyarakat menjadi penting untuk dipertimbangkan karena pernikahan dalam Islam bukan sekedar hubungan antara suami dengan isteri, tetapi juga berdampak bagi masa depan dan pendidikan anakanaknya, bahkan juga melibatkan dan mempengaruhi masyarakat disekitarnya. Surah Al Maidah diturunkan dalam periode Madinah, walaupun ada ayat yang diturunkan di Mekkah, namun itu terjadi ketika Rasulullah melaksanakan hajji wada'. Ketika Rasulullah memimpin 
masyarakat Madinah, kondisi intern umat Islam berada pada puncaknya, kendali kekuasaan sepenuhnya berada di tangan Rasulullah. Dalam konteks dengan masyarakat non muslim termasuk Ahli Kitab, posisi umat Islam adalah kalangan penguasa yang sangat berpengaruh Karenanya ketika seorang lelaki muslim menikahi perempuan Ahli Kitab maka fungsi da'wah melalui kepemimpinan suami dapat berjalan efektif. Pada sisi lainnya jumlah kaum muslimah masih agak terbatas, sehingga pernikahan satu dua orang muslim dengan perempuan kitabiyah belum memberikan dampak negatif bagi kaum muslimah. Dalam kondisi kemaslahatan menikahi perempuan Ahli Kitab masih dapat diharapkan dan kerugian (mafsadat) yang ditimbulkannya masih lebih kecil, maka membolehkan laki-laki muslim menikahi perempuan Ahli Kitab wajar diberikan oleh Al qur'an melalui ayat 5 surah al Maidah. (Karsayuda, 2006: 80)

Menurut Karsayuda (2006: 81-83) kondisi kemasyarakatan terus berkembang, karena itu hukum yang penetapannya terkait dengan perkembangan kehidupan masyarakat harus dinamis, sehingga tujuan hukum dapat tercapai. Memelihara agama baik bagi perorangan maupun masyarakat menjadi kewajiban semua pihak. Karena memelihara agama menjadi salah satu tujuan hukum Islam. Perubahan hukum karena perubahan masyarakat, bukan dimaksudkan agar hukum mengikuti apa yang terjadi, tetapi agar hukum dapat mengatur dan membatasi masyarakat. Agar masyarakat tidak keluar dan koridor yang diajarkan Allah, agar hukum dapat melindungi masyarakat dari kerusakan. Sebagaiman yang dinyatakan Ali Ahmad al-Nadawi (1994: 158) "Tidak dapat diingkari bahwa hukum yang didasarkan pada maslahat dan adat berubah karena perubahan zaman". Walau pada dasarnya menikahi wanita kitabiyah dibolehkan, namun ketika zaman telah berubah dan kerugian mengancam kehidupan umat Islam. Umar bin Khattab melarang laki-laki muslim menikahi Ahli Kitab. Tindakan ini diambil Umar dengan pertimbangan Sifat dan sikap Ahli Kitab dizamannya telah berubah, dan Tujuan dibolehkannya menikahi mereka tidak tercapai lagi.

Dibolehkannya mengawini wanita Ahli Kitab adalah dengan harapan mereka dapat ditarik masuk Islam atau setidaknya tidak memusuhi Islam. Namun kenyataannya di zaman Umar bin Khttab tujuan itu tidak tercapai lagi, bahkan menimbulkan dampak negatif lainnya, yaitu ada kecenderungan yang amat besar dari lelaki muslim menikahi wanita Ahli Kitab dari pada menikahi wanita muslimah. Menurut pandangan Umar hal ini amat berbahaya. Menurut Muhammad Rawwas alasan Umar bin Khattab tidak menyukai pernikahan lelaki muslim dengan wanita kitabiyah karena dua pertimbangan.

i. anak-anak mereka paling sedikit akan terpengaruh dengan agama ibunya. Umar menganggap isteri yang beragama ahlulkitab adalah 
batu sandungan bagi kelangsungan rumah tangga, dikhawatirkan akan ada pertentangan dalam rumah tangga mereka.

ii. hal itu akan menyebabkan wanita muslimah tidak laku nikah karena kehabisan kavling, dan memberikan angin segar kepada wanita ahlulkitab. (Rawwas, 1999: 414)

Sekiranya tujuan pernikahan dapat dicapai lagi, maka pada suatu saat menikahi Ahli Kitab dapat dibolehkan lagi. Secara metodologi Ushul Fiqh, tindakan Umar ini disebut Ijtihad Tatbiqi. Ketika Illat suatu nash tidak dijumpai lagi pada suatu objek hukum, maka hukum tersebut tidak dapat lagi diterapkan pada objek hukum tersebut. Dalam kasus pernikahan ini, Illat yang membolehkan lelaki muslim menikahi wanita Ahli Kitab adalah agar mereka bisa ditarik masuk Islam. Atas dasar itu, Umar melarang lelaki muslim mengawini wanita Ahli Kitab. Majelis Ulama Indonesia (MUI) dalam fatwanya yang dihasilkan dari Musyawarah Nasional II tanggal 11 17 Rajab 1400 H. Bertepatan dengan 26 Mei - 1 Juni 1980 M. Dengan pertimbangan mafsadat lebih besar dari pada maslahatnya, sejalan dengan ijtihad Umar bin Khattab ini dalam pengertian bahwa lelaki muslim, khususnya di Indonesia, dilarang kawin dengan wanita Ahli Kitab. Jika tujuan pernikahan itu tidak akan tercapai. Sayangnya pertimbangan lengkap mengenai besarnya mafiadat yang dilahirkan oleh pernikahan dengan wanita Ahli Kitab, tidak dijelaskan. Bila dikaitkan dengan Pasal 40 huruf c Kompilasi Hukum Islam, maka norma yang ada pada Kompilasi Hukum Islam tersebut bukan hal yang baru sama sekali, ia merupakan pengejawantahan dan hasil Munas II MUI. Karenanya pula Pasal 40 huruf c tersebut mendapatkan persetujuan dari peserta lokakarya yang merumuskan Kompilasi Hukum Islam. Maka dari itu pasal tersebut memenuhi aspek keadilan dan sesuai untuk kondisi masyarakat di Indonesia. Karsayuda, 2006: 88)

Analisis penulis mengenai pernikahan beda agama yang di kemukakan Karsayuda yaitu dengan menambahkan pertimbangan dari segi keharmonisanhubungan rumah tangganya yang tidak mudah dapat terj alin apabila pasangan suami istri tidak sepaham dalam ide, pandangan hidup atau agamanya. Tujuan utama dibolehkannya pernikahan seorang Muslim dengan wanita Ahil Kitab, adalah agar dengan pernikahan tersebut terjadi semacam penghubung cinta dan kasih sayang. Sehingga terkikis dari benak istrinya rasa tidak simpati terhadap Islam dengan sikap baik sang suami Muslim yang berbeda agama itu sehingga tercermin secara amaliah keindahan dan keutamaan agama Islam. Adapun jika sang suami Muslim terbawa oleh sang istri, atau anaknya terbawa kepadanya sehingga mengalihkan mereka dari akidah Islam, maka ini bertentangan dengan tujuan 
dibolehkannya pernikahan tersebut, dan ketika itu pernikahan tersebut disepakati untuk dibubarkan.

Berdasarkan ungkapkan oleh Rasyid Ridha dan Muhammad Abduh, bahwa yang dimaksud dengan Ahli Kitab adalah ahli tauhid (orang yang mengesakan Allah). Dari orang-orang sebelum Islam kemudian mereka ditimpa oleh fitnah kemusyrikan dari orang musyrik yang memeluk agama mereka, kemudian mereka terputus dengan masa lalu mereka. (Rasyid dan Abduh, TT: 177)

Majelis Ulama Indonesia memfatwakan perkawainan tersebut hukumnya haram". (Fatwa MUI, 2003,:169) Keharaman itu juga didasari dengan alasan bahwa para non Muslim tersebut bukan lagi dikategorikan sebagai Ahli Kitab, mereka telah berbeda dengan Ahli Kitab yang asli yang dimaksudkan oleh Q.S. Al-Ma'idah:5. (Mudzhar, 1993: 99-104)

Sejalan dengan uraian tersebut, Hazairin mengatakan bahwa kebolehan mengawini wanita kitabiyah tersebut seperti yang dikemukakan Allah. Dalam Q.S. Al-Ma'idah:5 adalah berupa dispensasi, karena suatu keadaan di mana ada kesulitan bagi pria muslim untuk mendapatkan wanita muslimah di sekitar mereka, karena memang jumlah wanita muslimah saat itu sangat sedikit. ( Pagar, 2006: 65) Sehubungan dengan kondisi Indonesia yang ada sampai saat ini ternyata tidak demikian halnya, karenanya dispensasi tersebut tidak boleh digunakan, artinya tidak boleh menikahi non muslim dengan alasan sulit untuk menemukan wanita msulimah, sedang mereka itu adalah tergolong wanita Kitabiyah. Kemungkinan kebolehan menikahi wanita kitabiyah ini hanya dapat dilakukan di Negeri-negeri yang penduduknya minoritas muslim, sedangkan wanita Kitabiyah banyak dijumpai di sana. Dengan demikian tidak diperkenankan bagi seorang muslim di Indonesia ini untuk menikahi wanita non muslim dengan alasan bahwa mereka itu adalah tergolong wanita kitabiyah.

Al-'Aqqad berpendapat hukum pernikahan yang baik ialah yang menjamin dan memelihara hakikat pernikahan, yaitu untuk menghadapi segala keadaan yang terjadi atau yang mungkin terjadi. Segala persoalan yang muncul dalam pernikahan sangatlah beragam, dari masalah yang sederhana sampai kepada persoalan kompleks. (Abbas, 985: 84.)

Segala sesuatu yang disyariatkan Islam mempunyai tujuan, sekurang-kurangya mengandung hikmah tertentu, tak terkecuali pernikahan.Tujuan pernikahan Islam tidak dapat dilepaskan dari pernyataan Al-Qur'an, sumber ajarannya yang pertama. Al-Qur'an menegaskan bahwa di antara tanda-tanda kekuasaan Allah. Ialah bahwa ia menciptakan istri-istri bagi para lelaki dari jenis mereka sendiri, agar mereka merasa tentram (sakinah). Kemudian Allah menjadikan/menumbuhkan perasaan cinta dan kasih sayang (mawaddah dan rahmah) di antara 
mereka.Dalam hal demikian benar-benar terdapat tanda-tanda (pelajaran) bagi mereka yang mau berfikir. Dalam bagian lain, Al-Qur'an menyatakan: para istri adalah pakaian (libas) bagi para suami, demikian pula sebaliknya, para suami adalah pakaian bagi istrinya.

Kehidupan yang tentram (sakinah) yang dibalut perasaan cinta kasih dan ditopang saling pengertian di antara suami dan istri karena "pakaian" bagi pasangannya itulah yang sesungguhnya merupakan tujuan utama disyari'atkannya pernikahan dalam Islam. Suasana kehidupan yang dituju oleh pernikahan serupa itu akan dapat dicapai dengan mudah apabila pernikahan dibangun di atas dasar yang kokoh, antara lain, antara suami dan istri ada dalam sekufu (Kafa'ah). (Sabiq, 1990: 30)

Dalam hal Kafa'ah baik Imam Hanafi, Maliki, Syafi'i, maupun Hanbali memandang penting faktor agama, sebagai unsur yang harus diperhitungkan.Bahkan Imam Syafi'i dan Imam Malik lebih menekankan pentingnya unsur ketaatan dalam beragama. (Al-Jaziri, TT: 58-61.)

Pentingnya Kafa'ah dalam pernikahan sangat selaras dengan tujuan pernikahan di atas. Suatu kehidupan suami-istri yang betul-betul sakinah dan bahagia. Suami istri yang sakinah dan bahagia akan mampu mengembangkan hubungan yang intim dan penuh kemesraan. Pada gilirannya akan melahirkan generasi selanjut yang baik dan salih, yang akan menjadi pemimpin orang-orang yang bertaqwa (lil muttaqina imama). (Sabiq, 1990: 44)

Melihat alasan dan argumentasi di atas maka semakin terang, bahwa ketentuan pernikahan berbeda agama, mampu menjangkau tujuan hakiki dari hukum Islam itu sendiri. Adanya keharusan memelihara agama dalam kemaslahatan manusia sulit tercapai jika mendapat gangguan dengan adanya andil pihak non muslim dalam menata kehidupan keluarga, yang sudah tentu akan tidak tinggal diam bagaimana ia untuk patuh dan berusaha menjadi seorang penganut kepercayaan dari agama yang diyakininya. Kondisi ini tentunya bertentangan dengan arus besar Islam yang sejak awal mencanangkan untuk menyemai nilai-nilai ketauhidan baik dalam diri maupun keluarga, seperti yang diperingatkan pada Q.S. Al-Tahrim ayat 6, yang memerintahkan manusia agar menjaga diri dan keluarganya dari api Neraka.

\section{KESIMPULAN}

Berdasarkan uraian pada bab sebelumnya penulis dapat menyimpulkan sebagai berikut: (a) Latar belakang Muhammad Karsayuda mengenai munculnya pemikiran hukum tentang pernikahan beda agama yaitu berdasarkan kehidupan masyarakat Indonesia yang dihadapkan pergaulan yang semakin meluas dan beragam, salah satunya seorang 
muslimin dan muslimat sekarang ini lebih berani untuk memilih pendamping hidup non-muslim. Dan di Indonesia sendiri terdapat perbedaan penetapan hukum mengenai pernukahan beda agama yaitu antara Kompilasi Hukum Islam dan Sumber Hukum Islam (Al qur'an dan Hadits). (b) Konsep hukum Muhammad Karsayuda mengenai penikahan beda agama yaitu ditinjau dari segi keadilan, Demokrasi, Sosial, dan Moral. keadilan demokrasi sendiri memandang bahwa keadilan yang harus dilindungi adalah keadilan orang banyak. mayoritas masyarakat Indonesia yaitu beragama Islam, bahwa Umat islam sendiri tidak menghendaki pernikahan beda agama. Alasannya karena agama non muslim di Indonesia (terutama keristen) sudah tidak berkeyakinan Kitabiyah (sesuai ajaran Nabi isa/musa). Sedangkan dalam konsep keadilan sosial, bahwa kesejahteraan rakyat dan keadilan yang diinsafi (disadari) oleh mayoritas rakyat yaitu umat Islam guna mencapai cita-cita yang luhur (terpeliharanya agama/keyakinan, dan terpeliharanya keturunan). Dan keadilan moral mengajarkan bahwa suatu keadilan dibangun dari hasil penilaian terhadap baik dan buruk. Bagi umat beragama, ajaran baik dan buruk yang paling dominan adalah ajaran agama. Dalam keadilan moral, keadilan itu adalah keadilan Tuhan, yang harus kita terima. Pada konteks ini aliran yang memahami al-Qur'an secara harfiah (tekstual) akan menganggap bahwa keadilan Tuhan itu adalah membolehkan laki-laki muslim menikahi wanita kitabiyah. Namun secara kontekstual, keadilan Tuhan itu adalah sebagaimana diatur Pasal 40 huruf c Kompilasi Hukum Islam. (c) Pendapat Muhammad Karsayuda mengenai pernikahan beda agama yaitu bahawa Ahli Kitab pada masa sekarang terutama di Indonesia termasuk kepada kaum musyrikin dikarenakan sudah tidak berkeyakinan Ahli Kitab (sesuai ajaran leluhurnya) akan tetapi menjadi penyembah berhala dengan menganut dogma Trinitas (konsep tiga Tuhan). Di Indonesia sendiri agama yang dikategorikan Ahli Kitab yaitu agama Kristen berdasarkan kondisi tersebut hukum menikahi wanita Ahli Kitab sudah menjadi di larang (haram). Maka dari itu pasal 40 (c) dalam Kompilasi Hukum Islam yang menyatakan bahwa seorang pria dilarang melangsungkan pernikahan dengan seorang wanita yang tidak beragama Islam memenuhi aspek keadilan dan sesuai untuk kondisi masyarakat di Indonesia.

\section{DAFTAR PUSTAKA}

Abbas Mahmud Al-'Aqqad. (1985). Falsafat Al-Qur'an. Dar al-Hilal. KairoMesir.

Abdurrahman. (1992). Kompilasi Hukum Islam di Indonesia. Akademi Presindo. Jakarta

Abdurrahman. (2010). Kompilasi Hukum Islam di indonesia. Akademika Pressindo. Jakarta 
Abdurrahman. Dudung. (2003). Pengantar Metode Penelitian. Kurnia Alam. Yogyakarta.

Ahmad Azhar Basyir. (2000). Hukum Perkawinan Dalam Islam Cer. IX.. UIIPress Yogya. Yogyakarta

Ahmad. Arjuna. (2014). nikah-beda-agama-dalam-islam. kompasiana.com

Aim Abdul Karim. (2006). pendidikan kewarganegaraan PT Grafindo Media Pratama

AI-Qur'an dan Terjemahnya. (1418 H. )Khadim al Haramain al Syarifain. Medinah..

Ali. Mohammad Daud. (1997). Hukum Islam Dan Peradilan Agama. P.T. Raja Grapindo Persada. Jakarta

Anonimous. (2007). Kompilasi Hukum Islam Indonesia dan Undang-Undang Republik Indonesia Nomor 1 Tahun 1974 tentang Perkawiinan. Trinity. t.k.

Ash-Shiddieqy Teungku Hasbi. (2000).Tafsir Al-Qur'an Majid An-Nuur. jilid 2. PT Pustka Rizki Putra. Semarang

Bustanul Arifin. (1996). "Kompilasi Fiqih dalam Bahasa Undang-undang". dalam Pesantren. No. 2Nol. 11/1985. hal. 25. dan Pelembagaan Hukum Islam di Indonesia. Akar Sejarah Hambatan dan Prospeknya. Gema Insani Press. Jakarta. .

Departemen Agama RI. (1992/1993). Kompilasi Hukum Islam di Indonesia. Dirbenpera Dirjen Pembinaan Kelembagaan Agama Islam Departemen Agama RI. Jakarta

Departemen Agama RI. (2000). Al-Qur'an dan Terjemahnya. CV.Asy-Syifa'. Semarang

Departemen Pendidikan dan Kebudayaan. (1996). Kamus Besar Bahasa Indonesia Edisi Kedua. Bal Pustaka. Jakarta.

M. Karsayuda. (2006). Perkawinan Beda Agama. Total Media. Yogyakarta.

Mahkamah Agung RI. (2002). Pedoman Pelaksanaan Tugas dan Administrasi Pengadilan. Buku II (edisi revisi). Jakarta.

MUI. (2003). Himpunan Fatwa Majelis Ulama Indonesia. Departemen Agama. Jakarta.

Nurcholish Madjid. (1997). Masyarakat Relegius. Paramadina. Jakarta.

Oemar Bakri. (1982). Tafsir Rahman. PT. Mutira. Jakarta

R. Soeroso. (2006) Pengantar Ilmu Hukum. Kamus dan Ensiklopedi.

Ramulyo. M. Idris. (1990). Tinjauan Beberapa Pasal Undang-Undang Nomor 1

Tahun 1974 Dari Segi Hukum Perkawinan Islam. IND-HILL-CO. Jakarta 
Rasyid Ridha. (1367 H). Tafsir Al Manar. Vol. VI. Darul Manar. Cairo

Republik Indonesia. (2001). Undang-Undang Nomor 1 Tahun 1974 Tentang Perkawinan Ditjen Binpera Islam Depag R.I. Jakarta.

Rifyal Ka'bah. (1999). Hukum Islam di Indonesia. Universitas Yarsi. Jakarta..

Yunus. Mahmud. (1977). Hukum Perkawinan dalam Islam. Hidakarya Agung. Jakarta.

Zuhaili. Wahbah. (2010). Fiqih Imam Syafi'i. Vol. 2. Penerjemah: Muhammad Afifi. et al. Almahira. Jakarta.

Zuhdi. Masjfuk. (1987). Masail Fiqhiyah. P.T. Toko Gunung Agung. Jakarta. 